
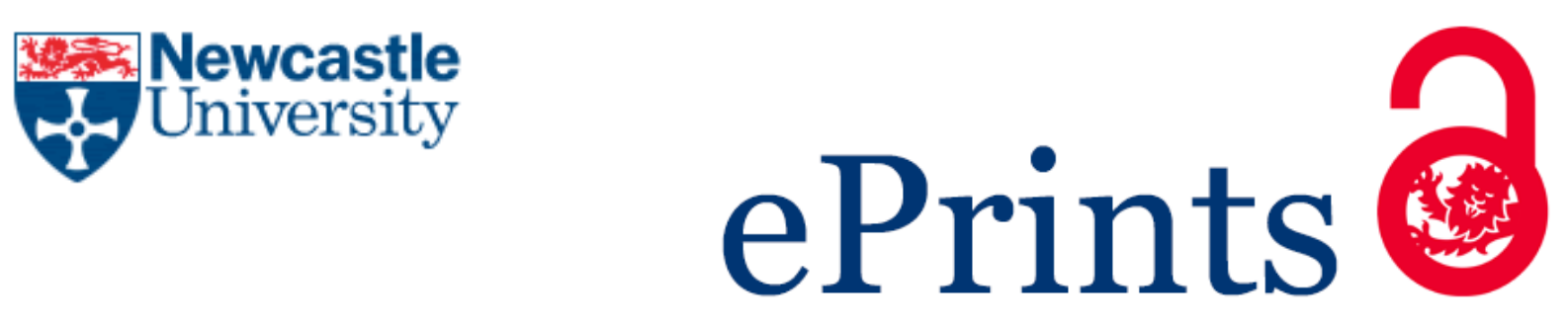

Labatut J, Munro I, Desmond J.

Animals and organizations.

Organization 2016, 23(3), 315-329.

\title{
Copyright:
}

This is the Authors' accepted manuscript of an article that was published in its final definitive form by Sage, 2016.

DOI link to article:

http://dx.doi.org/10.1177/1350508416629967

Date deposited:

$03 / 06 / 2016$

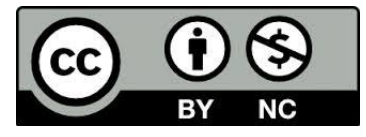

This work is licensed under a Creative Commons Attribution-NonCommercial 3.0 Unported License 


\section{Animals and organizations}

By

Labatut, J., Munro, I. and Desmond, J.

Published in 'Organization', 2016, 23(3): 315-329

'the animal must emerge again' (Nietzsche, 1998)

\section{Prologue}

A succession of scandals in the 1990s and 2000s brought animals and their role in human societies repeatedly into the public domain. Despite the fundamental role that animals play in human organization, this subject has been largely peripheral to organizational discourse and research (Lennerfors and Sköld, 2015). The present Special Issue may be seen as a modest attempt to address this shortcoming.When planning this Special Issue in early 2013, Europe was in the grips of the 'Horsegate' scandal. Horsemeat was found in meat products labelled as 'beef'. This heightened fears about the threat posed by industrial farming of animals, and reawakened memories of earlier threats from cows (BSE in the late 1980s), sheep and pigs ('foot in mouth' in 2001) and chickens ('campylobacter' in 2014). Elsewhere, the seemingly senseless destruction of wild animals, such as the killing of Cecil the lion by an American dentist on safari in Zimbabwe (reference), of whales by Japanese 'research' vessels in Antarctic water, and numerous other species, including great apes, dolphins and birdlife through habitat destruction has fuelled controversy over the exploitation of animals. Of course, there are also examples of when the animals 'fight back'. Las Vegas entertainers Siegfried and Roy were recently attacked by their own white tiger, Mantecore, who became angry during a performance, sinking his teeth into Roy's neck and dragging him off stage. At Sea World, trainers have been attacked and killed by the Orca whales, and there were 7227 reported canine attacks against people in the United Kingdom, often their owners, in a single year (Guardian, 2015). Such incidents commonly reveal the poor conditions in which animals are kept or are exploited. Clearly, Michel Callon's (1986) modest observation concerning the 'interessement' of scallops in the way they are fished could be developed to include more active animal agency.

Questions about animal agency recently rose to prominence, surprisingly perhaps, in the field of copyright law after an Indonesian macaque monkey took a 'selfie' with a photographer's cam- era, leading to a battle over who owned the copyright. The United 
States Copyright Office (2014) subsequently ruled that non-human animals cannot own copyright material and that this photograph should be in the public domain as 'A photograph taken by a monkey'. The role of animals as producers not only of nature but of culture would appear to be ambiguous, given the apparent need for laws that formally exclude them from this social domain. This case also highlights the long history of animal and human coevolution and particularly human dependence on, but dominance over, animals for food, as a means of transportation and more recently as treasured companion animals (Haraway, 2003; Shepard, 1997).

In order to frame such relations and their various 'agencies', this introduction is organized around three key theoretical problematics: agriculture and the biosocial organization of nature/ culture, ethics as the organization of the animal, and the politics of animal resistance. Discussion of each of the Special Issue's six papers is woven into the discussion of these problematics.

\section{Biosocial organization of nature/culture}

The historically unstable and permeable human/animal divide is the subject of a longstanding philosophical and anthropological debate. Anthropological studies were the precursors in the analysis of this question of relations between animals and human societies, although many anthropologists continue to see animals as 'a thing', and maintain a form of anthropocentrism linked to a certain idea of modernity (Manceron and Roué, 2009). Research in science and technology studies, however, has been at the forefront of the analysis of relations between animals and human societies and the emergence of new 'biosocialities'.

Rabinow (1996) and Haraway (2008) have argued, for example, that laboratory practices are already transforming our classical view of the boundaries of humanity, especially the demarcation between the animal and human kingdoms. Much of this work is influenced by Foucault's $(2003,2008)$ conception of 'biopolitics'-a concept of 'biopolitics' created to explain the historical development of political strategies for the administration of populations and for the optimization of the forces of life. The related concept of 'biosocial organization' (Rabinow, 1996) provides some conceptual space in which to express the diversity of our organized relations to animals in food production systems, resistance movements and ethical debates. 
The first domain where animals and organizations are intricately interlinked is agriculture and food production. In fact, as Lennerfors and Sköld (2015) show that 'the entire knowledge tradition of management, organization, and also economics' is 'firmly rooted in farm technology and agricultural affairs, concerned for instance with the productivity of oxen and horses' (p. 1). In line with this, Pina e Cunha et al. (2008) maintain that 'food may be thought of as a "total social phenomenon," an activity so pervasive in society that it directly or indirectly connects with every type of social phenomenon and institution' (p. 942). Agriculture and food production started with domestication, a practice at the root of the development of modern human societies (DeMello, 2012; Diamond, 2002; Ingold, 2011; Verrier et al., 2011). Domestication can be considered as the first historical form of biosociality. It allowed humans to have a steady food supply, new sources of labour, and new forms of companionship and protection (DeMello, 2012; Haraway, 1999). Agriculture and food production has triggered questions about the idea of nature as technics, which range from extreme technicization and production 'at a distance' to neo-traditional and family-based local or urban production. Whereas some authors see modernity as having 'dissolved the empirical animal into pure spectrality' (Burt, 2002: 26 in Marvin, 2005: 3); others, following Bruno Latour (1993), argued that far from being 'spectral', or ghost-like, animals are making a comeback in studies of social organization (see Hamilton and Taylor, 2012) including in works on the industrialization of livestock farming.

\section{Biosocial culture and industrializing animal production}

For the past few decades, the industrialization of livestock production has become a battleground of politics, policy, reform and education (Flowers and Swan, 2011), and a subject of investigation for understanding the issues of capitalism, globalization and management. Industrialized livestock operations and animal sciences, animal genetics and the food industry have participated in transforming animals into agricultural commodities and vehicles for capital accumulation (Boyd, 2001), 'units of production', machines (Ruet, 2004), 'nutritional laboratories' (A. Comte in (Lévi-Strauss, 2001)) and technologies (Schrepfer and Scranton, 2004). Far from being excluded from 'modern' societies, animals appear to be inextricably intertwined in the organizational processes and technologies of industrial capitalism.

One of the most salient examples of the industrialization of livestock production is the broiler industry (Boyd, 2001; Boyd and Watts, 1997; Horowitz, 2004). Boyd (2001) studied the application of mass-production techniques to agriculture and animals, with the transformation of biophysical and living systems into technological systems, that led the US 
broiler industry to be one of the most advanced systems of food production in the world. Integrated firms control most of the broiler production. This industry is a good example of the link between management systems and food production, through 'agro-industrial just-intime' (Boyd and Watts, 1997). These authors highlighted the important role of science (nutrition, health and genetics) in transforming both the biological productivity of broilers and the organization and management of the industry. Through industrial farming practices the chicken has become ontologically closer to a substrate for protein production than to a sentient being. The aim of the scientific and technological effort is to transform feed grains into chicken meat (cf. animal monocultures, Boyd, 2001: 652), as well as the 'disqualification' of the farmer from the process of food production. The industrialization of livestock production is an important object of analysis to understand modern capitalism, not only in terms of its internal organization, but also for its external effects in the ongoing transformation of (biosocial) nature. Described in such terms one can more readily understand the neat equivalences made by some policy advisors between units of production such as cows and cars in relation to their carbon emissions (Steinfeld et al., 2006).

\section{Biosocial criticisms of animal disease and suffering}

The 'industrial ecology' created by intensive farming has ramifications far beyond the farm (Boyd, 2001); in the proliferation of food-borne illnesses, antibiotic resistance, animal waste management, greenhouse gases and animal well-being. In this sense, the production of meat and the eating of animals has become a biopolitical space par excellence: 'a problem space, in which an array of connections appears between the individual and the collective, the technological and the political, the legal and the ethical' (Rabinow and Rose, 2006: 208)_one which has been the target of criticism on a global scale.

For example, agro-industralization and global health risks have revealed major problems with industrial farming and the relativity of the boundary between species (Milton, 2009; Porter, 2012). Animal diseases and food crises present an opportunity to study the micro processes of the government of life, as well as the role of science in biosocial organization (Enticott, 2001; Manceron, 2009; Manceron and Roué, 2009; Milton, 2009). For example, 'foot and mouth disease' resulted from a diminishing regard for safety and respect for both animals and consumers, where 'feeding ruminants on the scrapings of dead sheep's carcases proved not to be a smart idea' (Pina e Cunha et al., 2008: 951). Law and Mol (2008) have described this situation in terms of the 'metabolic relations' (p. 135) that exist between the virus, their animal hosts and people who may subsequently suffer harm from 
eating diseased animals. Since the widespread outbreak of 'mad cow' disease in the 1980s, it has become absolutely clear that humans constitute a biosocial community with farm animals and it is incumbent upon us to better appreciate the rules and metabolic relations that govern biosocial communities (Gouabault and Burton-Jeangros, 2010; Larrère and Larrère, 2004).

In contrast with industrial systems of farming, it is important to recognize too the existence of other systems of modern farming which allow for a regime of subjectification, where humans interact with animals as sentient, intelligent beings (Rémy, 2003). This is elaborated in the recent work from Porcher and Schmitt (2010) on how cows collaborate with farmers. For these authors, farmers define farming as 'living together' with animals in a hybrid community (Lestel, 1998), on the basis of a 'domestic contract' (Larrère and Larrère, 2004) that has been broken by industrial farming. Porcher and Schmitt (2010) describe how cows participate to the work of producing milk on the farm, showing that domestication is not always a synonym for alienation.

In this Special Issue, two papers focus on the organization of the livestock industry and industrial slaughter. Baran et al.'s (2016) paper seeks to better understand the 'dirty work' of industrialized animal slaughter and its effects on workers' well-being. This study reveals that slaughterhouse workers have lower physical and psychological well-being than other 'dirty' and 'low prestige' occupations. In contrast, Hamilton and McCabe's (2016) paper focuses on the work of meat inspectors and offers a detailed analysis of the emotional subjectivities of these workers, revealing a complex and contradictory mix of human-animal relations. Hamilton and McCabe's (2016) paper challenges any preconceived and simplistic views of the abattoir as dirty and violent organizations.

\section{New biosocialities in food systems?}

Another fruitful field of study for organization scholars is the development of new systems of organization in food and 'meat' production, ranging from, on the one hand, closer relations to animals (urban farming), and on the others, the exclusion of animals from food systems ('Beyond Meat' products). Alternative farming social movements are of interest to critical studies of organization, including the 'backyard chicken movement', often positioned as the antithesis of the factory farm (Galusky, 2014; Hamilton, 2014). These new forms of urban agriculture reconfigure relations between humans and animals, the power/knowledge relations between the animal sciences, farmers and citizens, and the rules and norms governing the breeding and killing of animals. 
As for the efforts to exclude animals from the food system, an increasing number of start-up companies are developing innovative ways of producing 'meat' and other agricultural products. Modern Meadow, for instance, has developed a 3D printer to 'print' meat. Hampton Creek Foods has created vegan 'eggs', presented as being cheaper, riskless and more sustainable than real hen eggs. Cultured Beef, a lab-grown meat product, was unveiled and cooked in August 2013. Silicon Valley has become involved in new forms of food production, where Biz Stone and Evan Williams of the social media company Twitter have invested in Beyond Meat, a start-up which proposes vegan products that look and taste like meat. One investor, Vinod Khosla, explains that agriculture is an old activity which rarely innovates: ' $15 \mathrm{~kg}$ of corn and 3000 litres of water are needed to produce $1 \mathrm{~kg}$ of beef: this represents a very low conversion rate of plant proteins into animal proteins. We can make this model at least five times more efficient' (Marin, 2014: 1). This investor sees 'vegetable meat' products as an opportunity for a more economically efficient industry, rather than as a moral issue of animal suffering. Some animal rights organizations also promote these new companies, and PETA (People for the Ethical Treatment of Animals) has declared Beyond Meat the company of the year in 2013. Dilworth and McGregor (2015) have called for critical scholars to 'move beyond the narrow, presumptive framings of in vitro meat as a technological remedy for our consumptive ills, to more seriously engage with the ethical consequences of this new form of food' ( $p$. 85). Current innovations in food production are moving towards a brave new biosocial world where agricultural innovation has moved from the farm to biotechnology companies and corporate giants of Silicon Valley. Given this we now turn to a more explicit discussion of animal ethics and attempts to navigate the divide that is presume to separate humans from those beings they call animals.

\section{Ethics as the organization of the animal}

The discussion of ethics in relation to the animal is organizational from top to bottom. The fate of living beings is determined on the basis that they fall on one or the other side of a divide prescribed by humans. However, as was mentioned in the previous section in relation to disease, humanity remains entangled within a messy 'animality' that clings to it despite the best efforts of philosophers to buttress the divide. The idea of a hierarchy between human and animal has an ancient provenance. Aristotle, in the Nichomachean Ethics allocates humanity a place above the plants and the animals in a hierarchy that proceeds in steps from matter to God. Humans are allotted their position based on their possession of reason, a property which Aristotle assumed to be peculiar to and thus defining of, humanity. It follows that for humans eudaimonia, to live well, involves the exercise and cultivation of 
this unique capacity for reason. He also argues in the Ethics that the appellation 'human' in relation to reason is synonymous across all social and political groupings. In relation to his first point, Nagel (1980) argues that a whiff of the animal persists where, 'occasionally it (reason) must act as janitor or pimp to the passions' (p. 11). In any event Aristotle's choice of reason as the idion, or defining characteristic peculiar to humanity, does not necessarily follow. Human cruelty might be a more apt choice than reason. As Hope has noted, 'there are many characteristics that are peculiar to human beings, other than rational activity, such as prostitution and burning ants with a magnifying glass, to name a few' (Hope, 2010: 7). Second, while in the Ethics Aristotle argues that all humans are identical in substance, in his political work he contends that the 'human' is homonymic, in that not all, for example, slaves, possess identically rational capacities, thus, 'some humans cannot lack and yet do lack a per se property of being human' (Ward, 2008: 77).

Aristotle's argument for a difference in degree between rational humans and irrational animals melded into the Christian notion that humanity has dominion over animals which exist to serve human ends. It was acknowledged, however, that animals feel pain. Influenced by the Stoics, Augustine wrote, 'We can perceive by their cries, that animals die in pain, although we make little of this since the beast, lacking a rational soul, is not related to us by a common nature' (Passmore, 1975: 197). Aquinas argued that righteous men who treat their beasts well will treat humans well, with the emphasis on the treatment of humans. Descartes' Discourse on Method marks a radical turn which effectively, 'ruins the very nature of the ancient cosmos' based on Aristotelian physics (Sutcliffe, 1968: 21). Where for Aristotle, differences between humans and animals are a matter of degree, for Descartes they are abyssal. Descartes $(1649,1968)$ famously promulgated the idea of the existence of a radical separation between the immaterial soul and the clockwork automaton comprising the human or animal body. Where in the ancient scheme, the human retains something of the animal, in this new figuration, a chasm opens between them. Answering a query by Mersenne in 1640, Descartes argued that animals cannot feel pain, because pain can only exist with understanding, which animals lack (Guerrini, 1989: 392). Descartes helped provide a conceptual framework and moral justification for 17th-century English and Dutch vivisectionists such as Robert Boyle and Robert Hooke. Given the assumption that humans have a soul and animals do not, it was argued that animals merely experience the external manifestations of pain which are purely mechanical responses to stimuli. On this basis, vivisection was not considered cruel. Given that Descartes extended the notion of a clockwork automaton to all bodies, this meant that when lacking a rational soul, the human body is not unique, leading ultimately to the corollary advanced by La Mettrie that man too 
is a mere machine (Guerrini, 1989: 398). It is noteworthy that it was only in 1987 that the paediatric profession formally acknowledged that human infants experience pain (Committee on Foetus and Newborn et al., 1987).

Given the above, it is unsurprising that the two main ethical questions have concerned animal suffering and the killing of animals. Peter Singer (1975) has been especially influential in summoning attention to the atrocious conditions suffered by sentient beings that are treated as clockwork machines in the factory farming system and in experimental research. His argument, which is based principally on preference utilitarianism is homonymic, that not all humans are persons whilst some animals are. Defining a person as an entity that is self-conscious, experiencing a continuous sense of the future and an apprehension of death, he argues that it is less justifiable to put a person to death than a non-person. Controversially, he argues that severely mentally disabled persons lack personhood because they lack a sense of continuous existence, while animals such as the higher apes, dogs, cats, whales and dolphins do. Such thinking is now reflected in policy. The argument to grant rights to cetaceans presented at the American Association for the Advancement of Science (Marino et al., 2010) led in 2011 to a proposal for a Declaration of Rights for Cetaceans. In 2013, the Indian government recognized cetaceans as non-human persons, and in 2014, the San Francisco Board of Supervisors ruled that cetaceans have the right to be free in their natural environment. Of course, it is usually considered taboo to eat dolphins, unless unintentionally as by-catch. Given their irresistible tastiness for some humans, one might assert with some confidence that the finding that pigs possess high-level cognitive abilities, (Marino and Colvin, 2015; Sayers, 2016 in this issue) will meet with a less enthusiastic response to calls for similar recognition.

Jacques Derrida (2008a) knowingly courted accusations of hyperbole when describing the 'unprecedented transformation' (p. 24) of the relation between humans and animals over the past 200 years. In particular, he raised the stakes in relation to Emmanuel Levinas, who spent time in a concentration camp during part of World War II, when stating,

One should neither abuse the question of genocide nor too quickly consider it explained away. It gets more complicated: the annihilation of certain species is indeed in process, but it is occurring through the organization and exploitation of an artificial, infernal, virtually interminable survival, in conditions that previous generations would have judged monstrous. (Derrida, 2008a: 24)

Three of the papers for this Special Issue investigate the killing of animals, where Baran et al. (2016) and Hamilton and McCabe (2016) focus on the organization of animal slaughter for food and a Hillier and Byrne (2016) investigate the organized extermination of feral 
animals. Discussing the results of a quantitative study, Baran et al. (2016) conclude that the process of slaughter has particularly negative psychological impacts on operatives compared to those engaged in other forms of 'dirty work', such as higher than average alcohol use and sleeplessness. This research raises interesting possibilities for developing an account of ethics as a form of embodied sympathetic reaction (see Ten Bos, 2011). It is worth noting that Baran et al.'s (2016) inquiry displaces concern from the one who is killed to the one who does the killing, who is now a victim.

In contrast to the account given by Baran et al. (2016), Hamilton and McCabe's (2016) study of factory inspectors does not understand this as 'dirty work' but provides a nuanced account of how live chickens pass from a 'dirty' zone that is alive with feathers and excrement to a 'clean' zone via an intermediary space comprising a gas chamber. Operatives work in the pristine sanitized environment of the clean zone where technological processes remove all ideas of the animal as a creature. This study of 'de-animalization' shows how living beings are reduced to the status of a commodity and reveals a remarkable capacity for humans to compartmentalize their emotions at work. On the one hand, the inspectors are inured to the process of animal slaughter that daily confronts them, providing this is painless for the animal. On the other hand, the same inspectors exhibited strong emotional attachments and compassionate feelings for other animals. This process of 'de-animalisation' resonates with another paper in the Special Issue by Hillier and Byrne (2016) which outlines the emergence of a 'dispotif of ferality' in Australia whereby erstwhile pets come to be portrayed as dangerously feral, alien, and carriers of foul diseases. As feral pests, these animals become subject to programmes of extermination. Both of these studies reveal how specific social and technological processes are employed to devalue the 'animal other' or exclude this other from explicit moral consideration.

The exclusion of the animal other from the moral realm invites brief consideration of the work of Peter Singer and Jacques Derrida. Of the two, Derrida has received much more prominence in recent years perhaps because his work on the animal came close to his death. It is rather curious that while emphasizing Bentham's question of whether animals can suffer (Derrida, 2008a: 27), nowhere in his voluminous work on the animal does he mention Singer. Singer (1993) is careful when using the signifier 'animal', to argue that, 'even in the restricted sense of "non-human animal"- -this covers too diverse a range of lives for one principle to apply to all of them' (p. 131). Acknowledging the difficulties, he develops the argument described above in relation to personhood, into the requirement for some kind of hierarchy; 
Some say that it is anthropocentric, even speciesist, to order the value of lives in a hierarchical manner. If we do so we shall be inevitably placing ourselves at the top and other beings closer to us in proportion to the resemblance between them and ourselves. (Singer, 1993: 105)

Nonetheless, he argues that this does not present an insoluble problem and that it is possible to take a neutral stance. His retention of the idea that hierarchy is important is a key point of disagreement with Derrida who otherwise shares Singer's concern with the use of blanket term 'animal'. Derrida is scathing of philosophers, accusing them of an all too human bêtise, 'an inanity, asinanity and brute stupidity' (Krell, 2013: 19), when attempting to gather up and contain all living non- human nature under the collective signifier 'the animal', as such, counterposed to the realm of 'the human, as such'. Such categorization, he argues, acts solely in the interests of human power over the animal. Classification is related to the scopic drive he calls the vizier effect, which is the drive to see the other in order to know them, the better to possess them, cage them and do violence to them, without being seen oneself (Derrida, 2009). Alternatively, what if the other we call the animal sees us in our naked vulnerability?

Derrida refuses to use the signifier 'animal', for which, he substitutes 'animot', arguing that we should refuse the temptation to categorize but should rather respond to the uniqueness of every living being we encounter. All thinking about the animal is fundamentally carnophallogocentric, so there is a need for an entirely new language (see also Sayers, 2016 in this Special Issue). In amalgamating these terms in such a way that 'carno' comes first, Derrida signals the division of the human from the non-human to be primary and fundamental. The use and abuse of animals is thus deeply ingrained in the construction of human, particularly male subjectivity. A nested hierarchy is assumed, where man is taken to be superior to woman, adults over children and humans over animals.

The paper by Janet Sayers (2016) in this issue focuses on the routine mass slaughter of pigs to argue for the need to unsettle carnophallogocentric thought which sustains such monstrous practices and to develop new ways of writing about the animal. The vegetarianism argued for by Singer in this context is clearly insufficient because as Sayers notes, Derrida argues that what constitutes the animal is digested and projected in complex symbolic and material ways. It can be argued too that vegetarianism invites misplaced feelings of good conscience in the face of an incalculable responsibility to 'animal others'. While Sayers' discussion of the fetishistic disavowal of the animal is illuminating, one might argue that Derrida points to an even more radically split subject when mentioning, 'this disavowal, this foreclosure' of those philosophers who disavow the animal (our italics) 
(Derrida, 2008b [2002]: 112), where in a psychoanalytic understanding, foreclosure describes the subject, not of perversion, but psychosis. Sayers summons attention to the need to shatter the walls of discourse that buttress carnophallogocentrism, drawing on Kafka and Haraway as inspirations for how novel forms of poetic and satirical 'pig-writing' might be developed as an alternative. It is important to note in this context that Derrida did not merely argue for what might be perceived to be a rather abstract engagement in the deconstruction of carnophallogocentrism, but also to court undecideability in our every decision concerning those other beings we daily encounter; who do we give priority to and why when confronting the irreplaceable singularity of those other beings we rear, those we hunt for sport, or who entertain us, who live with us, whose flesh we eat, whose skin we wear as clothing. Derrida's response to Aristotelian reasoning concerning the idion of humankind is to destroy the hierarchy and align himself instead with the chimaera, considered monstrous because of its multiplicity, having the, 'head and chest of a lion, entrails of a goat, tail of a dragon', which was banished from the cogito in the fourth part of Descartes' Discourse on Method (Derrida, 2008a: 41, 46).

\section{The politics of animal resistance}

While the previous section on ethics discusses the human tendency to place the animal in a hierarchical arrangement the better to control it, in this section, we discuss how the animal has played a distinctive political role in relation to the concept of resistance as a form of inversion of hierarchy both in popular culture and in more philosophical critiques of the hegemonic social order. Animals are a rich source of inspiration for forms of resistance movements. Historically, animals have been looked upon as the ultimate rebels from the ethics of the ancient Cynics, to the rebel slave stories of Brer Rabbit, and to more recent literary tales such as Orwell's Animal Farm. This final section will explain this relationship between resistance and the animal in terms of three general propositions: (1) animal resistance represents a 'world turned upside down', (2) strategies of resistance express biophilia, and a friendliness towards animal life, and (3) strategies of resistance embody a becoming animal.

\section{Animal resistance as a 'world turned upside down'}

Animals teach us about man's domination of nature in general. Revolution and social reorganization inverts existing relations of domination in a 'world turned upside down'. In James C. Scott's (1990) account of the arts of resistance he noted that animals commonly 
appeared as a key motif in the fables of rebellious peasants during the revolts of Middles Ages and the oral tradition that underpinned resistance to slavery. Scott (1990) described these fables as a part of a process of 'symbolic inversion' where animals were used to portray another world in which the traditional social order had been turned upside down. In these stories,

Mice ate cats, children spanked parents, the hare snared the hunter, the car pulled the horse, fisherman were pulled from the water by fish, the wife beat the husband, the ox slaughtered the butcher, the poor man gave alms to the rich man, the goose put the cook into the pot, the king on foot led a peasant on horseback, fish flew in the air ... The underdog took revenge ... (Scott, 1990: 167)

These anonymous tales were an important way in which oppressed peoples could achieve a 'voice under domination' (Scott, 1990: 166).

Orwell's allegory of the betrayal of social revolution in Animal Farm is very much an inheritor of this tradition, where the animals overthrow the exploitative rule of their human master, $\mathrm{Mr}$ Jones, to create a new utopia in which all animals are equal, but matters go quickly awry. The revolutionary pig, Snow Ball, is killed by Napoleon, who installs a new managerial class of pigs on the farm. A more austere regime of exploitation is soon installed in the farm by the pigs, where the other animals are worked to exhaustion and death. Instead of a wellearned peaceful retirement, Boxer the workhorse is sent to the knackers yard and sold by the pigs for his meat. The full tragedy of the bogus revolution becomes all too clear in the closing pages of the book when Napoleon the pig sits down once again with the human masters, and the old system of capitalism reasserts itself, but this time with the pigs acting as the agents for the masters. The book ends with the animal workers peering though the farmhouse window at a meeting between the pigs and humans, 'The creatures looked from pig to man, and from man to pig, and from pig to man again: but it was already impossible to say which was which' (Orwell, 2000: 102)1.

In Orwell's allegory, he noted how the pigs assumed authority over the other animals by virtue of their supposedly superior knowledge, as the 'brain workers' of animal farm- 'The pigs did not actually work, but directed and supervised the others. With their superior knowledge it was only natural that they should assume leadership' (Orwell, 2000:19). This division of labour and the creation of a distinct class of managers (the pigs) was the first major betrayal of the revolution. It is only a matter of time before the original constitution of the animal rebellion is amended to 'All animals are equal but some animals are more equal than others'. This situation is only too familiar to scholars in the United Kingdom, Australia 
and other countries which conduct a research assessment exercise in order to manage their scholars. This exercise has resulted in the establishment of a class division between teachers and researchers ('brain workers') which is enforced by research assessment 'swinocrats', who claim that all animals are equal ('peers'), but of course, some are more equal than others, and ensuring this inequality is the whole purpose of the research assessment exercise. As editors we acknowledge our complicity in this process because, although the journal editorial system is quite different from the research assessment exercise, the latter system is heavily reliant upon the former. As Animal Farm academics we ourselves may repeat the squeals of the research assessment Napoleons, ' 4 stars good, 2 stars bad'.

In the work of both Orwell (2000) and Scott (1990), the animal is the example par excellence of the exploited being, used and abused as a source of labour power and as a source of food for the masters. In this context, animal stories are not pure analogies but reveal the very essence of exploitation and the structure of exploitative social relations.

\section{Strategies of resistance express biophilia, a friendliness towards animal life}

Historically, biophilia has often been expressed in resistance movements, from the ancient cynicism of Diogenes to the founding of animal protection social movement organizations such as the Royal Society for the Protection of Animals, Greenpeace and the Sierra Club. The 'animal existentialism' advocated by Peter Sloterdijk (1987) suggests that animality is a source of great revolutionary potential in the arts, social theory and social movements more generally. This springs from the Cynic movement in ancient Greece which was critical of the elitist ethics of that time, instead advocating that people live according to a certain conception of nature, bearing witness to their true animal being. Sloterdijk (1987) himself proposed that cynicism uses 'bodies as arguments, bodies as weapons' (p. 109) and expresses a biophilia that is a 'code word for creative friendliness toward life' (p. 126). The cynic sticks out his tongue, laughs, farts, pisses, bares his arse. Sloterdijk sees this style of critique at work in the Dada art movement, in psychoanalysis, and in the hippie movements of the 1960s. Even though his work is politically conservative in orientation, it still highlights the radicality of animal being as a rich source of social and aesthetic critique.

Foucault (2011) also observed that ancient cynicism broke with the hegemonic conceptions of ethics of the rulers of the ancient world that were focused on training elites in the arts of government. In contrast, cynicism was a universalist ethic which was open to the poor and to women who were otherwise excluded from the ethical schools of the ancient Greek world. Foucault (2011) traced the influence of the Cynic technique of 'bearing witness' through 
ones way of life in the revolutionary actions of Methodist groups in the French Revolution and Quaker groups in the American Revolution. Both Foucault (2011) and Sloterdijk (1987) saw animality as a revolutionary practice that appeared in different guises in the ideals and practices of revolutionary social movements, from ancient cynicism to more modern critical movements (Munro, 2014).

\section{Strategies of resistance embodying a becoming animal}

The animal is typically appealed to in the rituals of social exclusion and bestialization that make up fascist, genocidal forms of organization. Bauman (1991) characterized this appeal as an effect of the social and moral distancing of bureaucratic organizations and Esposito (2012) has described as resulting from an 'immunitarian' politics that aims to protect itself against the alien and inhuman. However, we must be wary of giving the animal a negative evaluation in any account of biosocial organization (e.g. reduced to the status of vermin or the subhuman). A key task of post-humanist thought has been to overcome the exclusionary tendencies of immunitarian politics (Deleuze and Guattari, 1988; Esposito, 2012; Massumi, 2014). It is in precisely this light that Esposito (2012) explains the concept of 'becoming animal' as reaching towards the outside to the animal mulitiplicities within us. Becoming animal involves processes of molecular deterritorialization and the creation of lines of escape that bypass exclusive molar groups. As Esposito explains

Becoming animal, for Deleuze, does not signify sinking into the dark pit of the human being; nor is it a metaphor or a literary phantasm. On the contrary, it is our most tangible reality, so long as what we mean by real is the process of mutation that our nature has always undergone. (Esposito, 2012: 150)

Becoming animal is a line of escape beyond the molar forces of the Oedipal family, the bureaucracy, or the law. It is one of the key revolutionary processes proposed by Deleuze and Guattari $(1986,1988)$ where the human is deterritorialized as an animal pack or an insect swarm. Deleuze and Guattari (1988) focus on the way in which we form rhizomes with animal nature through symbiosis and parasitism, through the transversal communication of genes, and in acting as nomadic packs and insect swarms, which all enhance our powers of metamorphosis.

Becoming animal is not at all the same as mimicry of an animal. As Brian Massumi (2014) has argued, 'play' is one of the key processes through which 'becoming animal' occurs. Our becoming animal subsists in the activity of creative play and the powers of metamorphosis of human and non-human animals. When engaged in play, the animal uses performative 
gestures and symbolic abstractions, exemplified by the gesture of 'this is not a bite'. Massumi (2014) argues that through play we can deterritorialise ourselves and enter the 'animal existential territory' (p. 55). Play and becoming animal are both aspects of biophilia. Existing research within the field of organization studies on power and resistance has sadly neglected the significance of the animal in these relations. This Special Issue is in part a response to this neglect, highlighting the active role of animal agency in the process of organization. We have already discussed how animals come to be seen as passive actors not as a result of natural behaviour but as the result of a process of 'de-animalization' in the industrial slaughterhouse where they are systematically stripped of any agency or value other than as a commodity in a capitalist circuit of exchange (Hamilton and McCabe, 2016). In contrast to those studies in this Special Issue which investigate the treatment of animals as food (Baran et al, 2016; Hamilton and McCabe, 2016) and as feral pests (Hillier and Byrne, 2016), one paper investigates the active agency of animals showing how they are 'constitutively entangled' within organizing processes in the construction industry (Sage et al., 2016). This study by Daniel Sage and his colleagues shows that the animal other is not simply excluded from organization and that in addition to processes of exclusion, other processes of 'disturbance' and 'invitation' exist in organizations that reveal a range of approaches to negotiating human-animal boundaries. The active agency of animals in organizations is the subject of another paper in this Special Issue; a paper that explores the role played by Olly the cat when she is invited to live in an international airport (O'Doherty, 2016). The cat acts as a companion animal for some, as a public relations opportunity for others and also as a disruptive creature which becomes the focus for competing expressions of organizational politics. Both articles thus reveal the animal as an active participant in the dynamics of organizational micro politics and in the negotiation of organizational boundaries. This introduction began by considering examples of animals as both victims of modern industrial capitalism and as rebels who occasionally turn against their human keepers. This final section of the introduction has highlighted the role of animals in subverting the prevailing biosocial order of the modern world, in terms of, (1) animal resistance that represents a critique of the social order as a 'world turned upside down'; (2) strategies of resistance that express biophilia, a friendliness towards life; and (3) strategies of resistance that embody a becoming animal. Animals are not simply to be protected by their human masters, rather animality and becoming animal are rich sources of rebellious and revolutionary action. These propositions rediscover animality as an ethics which expresses a respect of the animal other and a friendliness towards life. 


\section{Conclusion}

This Special Issue has investigated aspects of the role played by animals in the process of organizing, and of the organizational framing of the treatment of animals. This raises important questions not only relating to methodology, epistemology and ethics of organization, but fundamentally to the virtual exclusion until now of discussion of animals within organization theory. The papers in this issue point towards the need for further research and theorizing in relation to the animal and organization. From Baran et al. (2016), further study is needed as to the possible existence of a sympathetic bodily connection between those workers at the bottom of the pyramid who engage in animal slaughter and those they routinely kill. Hamilton and McCabe (2016) summon our attention in relation to the meat inspectors they interviewed, to the idea that there is no necessary contradiction between the process of 'de-animalising' and separating those animals that are slaughtered, from other animals towards whom an emotional connection is retained. Linked to this we are on the one hand treated to a discussion of the extraordinary lengths humans will go to in order to secure the habitat of a species deemed protected (Sage et al., 2016) and to the equally impressive lengths they will go to in seeking to exterminate as vermin, an erstwhile family pet (Hillier and Byrne, 2016). As Sayers (2016) argues from Derrida (2008a), this schizoid relation to that blanket category that humans label 'the animal' is reflected in our real and symbolic ingestion and projection, of a carnophallogocentric order that privileges a nefarious hierarchy, which at times becomes a chasm to separate human from animal. Sayers' paper argues the need for new forms of writing which bring carnophallogocentrism into question.

Common to all of these studies is a concern for animal ethics, animal agency, and the way in which 'biosocial organization' is a fundamental aspect of the development of organizations. These studies propose a number of possible ways of developing the field, including through actor network theory, through animal ethnographies, through deconstructive analysis and through the historical analysis of techniques of power in formation of animal 'dispositifs'. While recognizing the challenge presented to organizational scholars in seeking to apply the conceptual schemes of authors such as Deleuze, Callon and Latour to questions of organization in relation to the animal it is also important to question the adequacy of such organizing frames to fully comprehend creatures comprised of flesh and blood (Krell, 2013: 152-153). Finally, by focusing on our organized relations to animals, this Special Issue seeks to venture beyond zoocentric perspectives to open research avenues for organization and management scholars in adopting an 'ecocentric' 
perspective considering human organizations as part of a community involving animals, plants and the environment.

\section{References}

Baran, B., Rogelber, S. and Clausen, T. (2016) 'Routinized Killing of Animals: Going beyond Dirty Work and Prestige to Understand the Well-Being of Slaughterhouse Workers', Organization, IN PRESS.

Bauman, Z. (1991) Modernity and the Holocaust. Cambridge: Polity Press Boyd, W. (2001) 'Making Meat. Science, Technology and American Poultry Production', Technology and Culture 62: 631-64. Boyd, W. and Watts, M. (1997) 'The Chicken Industry and Postwar American Capitalism', in D. Goodman and W. Michael (eds) Globalising Food: Agrarian Questions and Global Restructuring, pp. 192-225. Hove: Psychology Press. Callon, M. (1986) 'Eléments pour une sociologie de la traduction. La domestication des coquilles Saint- Jacques et des marins-pêcheurs de la baie de Saint-Brieuc', L'Année Sociologique Numéro spécial La sociologie des Sciences et des Techniques 36: 169-208. Committee on Foetus and Newborn, Committee on Drugs, Section on Anesthesiology, et al.

'Neonatal Anaesthesia',

Pediatrics

80(3):

44.

Deleuze, G. and Guattari, F. (1986) Kafka: Toward a Minor Literature. Minneapolis, MN: University of Minnesota Press. Deleuze, G. and Guattari, F. (1988) A Thousand Plateaus: Capitalism and Schizophrenia. London; Bloomsbury Publishing. DeMello, M. (2012) Animals and Society: An Introduction to Human-Animal Studies. New York: Columbia University Press. Derrida, J. (2008a) 'The Animal That Therefore I Am; More to Follow', in M.-L. Mallet (ed.) Derrida, Jacques, The Animal That Therefore I Am (Perspectives in Continental Philosophy, trans. D. Wills, series ed. J. D. Caputo), pp. 1-52. New York: Fordham University Press. Derrida, J. (2008b [2002]) 'And as for Me, Whom Am I (Following)?', in M.-L. Mallet (ed.) Derrida, Jacques, The Animal That Therefore I Am (Perspectives in Continental Philosophy, trans. D. Wills, series ed. J. D. Caputo), pp. 52-119. New York: Fordham University Press. Derrida, J. (2009) The Beast and the Sovereign, vol. 1 (ed. M. Lisse and M.-L. Mallet, with G. Michaud, trans. G. Bennington). Chicago and London: The University of Chicago Press. Descartes, R. (1649) 'Principles of the Soul: Part 1: The Mind and the Body', s 6, lines 5360: 9. Retrieved from http://www.corwin.com/upm-data/23183_Chapter_11.pdf 
Descartes, R. (1968) Discourse on Method, and Other Writings (Translated with an Introduction by F. E. Sutcliffe). London: Penguin.

Diamond, J. (2002) 'Evolution, Consequences and Future of Plant and Animal Domestication', Nature 418(6898): 700-7.

Dilworth, T. and McGregor, A. (2015) 'Moral Steaks? Ethical Discourses of In Vitro Meat in Academia and Australia', Journal of Agricultural and Environmental Ethics 28(1): 85-107.

Enticott, G. (2001) 'Calculating Nature: The Case of Badgers, Bovine Tuberculosis and Cattle', Journal of Rural Studies 17: 149-64.

Esposito, R. (2012) Third Person (tans. Z. Hanafi). Cambridge: Polity. Flowers, R. and Swan, E. (2011) "Eating at Us": Representations of Knowledge in the Activist Documentary Film Food, Inc.', Studies in the Education of Adults 43(2): 234-50. Foucault, M. (2003) Society Must Be Defended: Lectures at the Collège de France, 19751976. Basingstoke:

Palgrave

Macmillan.

Foucault, M. (2008) The Birth of Biopolitics: Lectures at the College de France 1978-1979. Basingstoke:

Macmillan.

Foucault, M. (2011) The Government of Self and Others: Lectures at the College de France, 1982-1983. Basingstoke: Palgrave Macmillan.

Galusky, W. (2014) 'Technology as Responsibility: Failure, Food Animals, and Lab-Grown Meat', Journal of Agricultural and Environmental Ethics 27(6): 931-48. Gouabault, E. and Burton-Jeangros, C. (2010) 'L'ambivalence des relations humain-animal: une analyse socio-anthropologique du monde contemporain', Sociologie et sociétés 42(1): 299-324.

Guerrini, A. (1989) 'The Ethics of Animal Experimentation in 17th Century Experimentation in England', Journal of the History of Ideas 50(3): 391-407. Hamilton, J. A. (2014) 'Year of the Chicken', Science as Culture 23(1): 124-8. Hamilton, L. and McCabe, D. (2016) “'It's Just a Job”: Understanding Emotion Work, DeAnimalization and the Compartmentalization of Organized Animal Slaughter', Organization, IN

PRESS.

Hamilton, L. and Taylor, N. (2012) 'Ethnography in Evolution: Adapting to the Animal "Other" in Organizations', Journal of Organizational Ethnography 1(1): 43-51. Haraway, D. (1999) 'A Cyborg Manifesto', in S. During (ed.) The Cultural Studies Reader, pp. 271-92. London: Routledge.

Haraway, D. (2003) The Companion Species Manifesto: Dogs, People and Significant Others. Chicago: Prickly Paradigm Press. Haraway, D. J. (2008) When Species Meet. Minneapolis, MN: University of Minnesota 


\section{Press.}

Hillier, J. and Byrne, J. (2016) 'Is Extermination to be the Legacy of Mary Gilbert's Cat?', Organization,

IN

PRESS.

Hope, M. (2010) Aristotle's Ethics: Moral Development and Human Nature. New York: Continuum. Horowitz, R. (2004) 'Making the Chicken of Tomorrow: Reworking Poultry as Commoditites and as Creatures, 1945-1990', in S. R. Schrepfer and P. Scranton (eds) Industrializing Organisms, pp. 215-36. New York: Routledge. Ingold, T. (2011) 'From Trust to Domination: An Alternative History of Human-Animal Relations', in A. Manning and J. Serpell (eds) Animals and Human Society: Changing Perspectives, pp. 1-22. London:

Routledge.

Krell, D. F. (2013) Derrida and Our Animal Others: Derrida's Final Seminar, 'The Beast and the Sovereign'. Bloomington, $\mathbb{I N}$ and Indianapolis, IN: Indiana University Press. Larrère, C. and Larrère, C. (2004) 'Actualité de l'animal-machine', Sens Public 09: 1-17. Latour, B. (1993) We Have Never Been Modern. Cambridge, MA: Harvard University Press. Law, J. and Mol, A. (2008) 'Globalisation in Practice: On the Politics of Boiling Pigswill', Geoforum 39: 133-43.

Lennerfors, T. T. and Sköld, D. (2015) 'The Animal', in 34th Standing Conference on Organizational Symbolism, Uppsala University, Uppsala, 11-14 July.

Lestel, D. (1998) 'L'innovation cognitive dans des communautés hybrides homme/animal de partage de sens, d'intérêts et d'affects', Intellectica 26: 27.

Lévi-Strauss, C. (2001) 'La leçon de sagesse des vaches folles', Etudes rurales 157-8: 914.

Manceron, V. (2009) 'Grippe aviaire et disputes contagieuses. La Dombes dans la tourmente', Ethnologie française 39(1): 57-68. Manceron, V. and Roué, M. (2009) 'Les animaux de la discorde', Ethnologie française 39(1): 5-10.

Marin, J. (2014) 'Ces start-up qui veulent révolutionner l'agroalimentaire', Retrieved from http://siliconval-ley.blog.lemonde.fr/2014/02/10/ces-start-up-qui-veulent-revolutionnerlagro-alimentaire/

Marino, L. and Colvin, C. M. (2015) 'Thinking Pigs: A Comparative Review of Cognition, Emotion, and Personality in Sus Domesticus', International Journal of Comparative Psychology 28. Retrieved from http://escholarship.org/uc/item/8sx4s79c Marino, L., Reiss, D. and White, T. I. (2010) 'Intelligence of Dolphins: Ethical Policy Implications', in AAAS, San Diego, CA, 18-22 February. 
Marvin, G. (2005) 'Guest Editor's Introduction: Seeing, Looking, Watching, Observing Nonhuman Animals', Society and Animals 13(1): 1-12. Massumi, B. (2014) What Animals Teach Us about Politics. Durham, NC: Duke University Press.

Milton, K. (2009) 'Science and Personhood on the Farm. Cattle in Crisis in the UK', Ethnologie française 39(1): 69-78. Munro, I. (2014) 'Organizational Ethics and Foucault's 'Art of Living': Lessons from Social Movement Organizations', Organization Studies 35(8): 1127-48. Nagel, T. (1980) 'Aristotle on Eudaemonia', in Oksenberg Amelie Rorty (ed.) Essays on Aristotle's Ethics, pp. 7-14. Berkeley; London: University of California Press. Nietzsche, F. (1998) On the Genealogy of Morality. Indianapolis, IN: Hackett Publishing. O'Doherty, D. (2016) 'Feline Politics in Organization: The Nine Lives of Olly the Cat', Organization, IN PRESS. Orwell, G. (1994) 'The Lion and the Unicorn', in G. Orwell (ed.) George Orwell: Essays, pp. 138-88. London: Penguin. Orwell, G. (2000) Animal Farm. London: Penguin. Passmore, J. (1975) 'The Treatment of Animals', Journal of the History of Ideas 36: 195218.

Pina e Cunha, M., Cabral-Cardoso, C. and Clegg, S. (2008) 'Manna from Heaven: The Exuberance of Food as a Topic for Research in Management and Organization', Human Relations 61(7):

935-63.

Porcher, J. and Schmitt, T. (2010) Les vaches collaborent-elles au travail ? Une question de sociologie. Revue du Mauss 35(1): 235-261. Porter, N. (2012) 'Risky Zoographies: The Limits of Place in Avian Flu Management', Environmental Humanities 1 :

103-21.

Rabinow, P. (1996) 'Artificiality and Enlightenment: From Socio-Biology to Biosociality', in P. Rabinow (ed.) Essays on the Anthropology of Reason, pp. 91-111. Princeton, NJ: Princeton University Press. Rabinow, P. and Rose, N. (2006) 'Biopower Today', BioSocieties 1:

195-217.

Rémy, C. (2003) 'Une mise à mort industrielle « humaine "? L'abattoir ou l'impossible objectivation des animaux', Politix 16: 51-73. Ruet, F. (2004) 'De la vache machine en élevage laitier', Quaderni 56: 59-69. Sage, D., Justesen, L., Dainty, A., et al. (2016) 'Organizing Space and Time through Relational Human- Animal Boundary Work: Exclusion, Invitation and Disturbance', Organization, 
Sayers, J. (2016) 'Report to an Academy: On Carnophallogocentrism, Pigs, and MeatWriting', Organization, IN

PRESS.

Schrepfer, S. R. and Scranton, P. (2004) Industrializing Organisms, Introducing Evolutionary History. New York and London: Routledge. Scott, J. C. (1990) Domination and the Arts of Resistance: Hidden Transcripts. New Haven, CT: Yale University

Press.

Shepard, P. (1997) The Others: How Animals Made Us Human. Washington, DC: Island Press.

Singer, P. (1975) Animal Liberation: A New Ethics for Our Treatment of Animals. New York and London: New York Review \& Random House.

Singer, P. (1993) Practical Ethics. Cambridge: Cambridge University Press. Sloterdijk, P. (1987) Critique of Cynical Reason (trans. M. Eldred). Minneapolis, MN: University of Minnesota

Press.

Steinfeld, H., Gerber, P., Wassenaar, T., et al. (2006) Livestock's Long Shadow: Environmental Issues and Options. Rome: Food and Agriculture Organization, United Nations.

Sutcliffe, F. E. (1968) Introduction to Descartes Discourse on Method and the Meditations. Harmondsworth:

Penguin. Ten Bos, R. (2011) 'The Moral Significance of Gestures', Business Ethics: A European Review 20(3): 280-291. The Guardian (2015) 'Hospital Admissions for Injuries Caused by Dogs up 76\% in 10 Years', Retrieved from http://www.theguardian.com/uk-news/2015/may/28/hospital-admissions-forinjuries-caused-by-dogsup-76-over-past-10-years The United States Copyright Office (2014) 'Compendium of U.S. Copyright Office Practices', Retrieved from http://copyright.gov/comp3/docs/compendium.pdf Verrier, E., Brives, H. and Heams, T. (2011) 'Races animales, éleveurs et sociétés: évolution d'un concept et des pratiques de sélection', CGAAER/OIE colloquim on L'évolution des relations entre l'homme et l'animal: une approche transdisciplinaire, 29 Novembre 2011; (2 pp.). Paris. Ward, J. K. (2008) 'Is Human a Homonym for Aristotle?', Apeiron 41(3): 75-98.

\section{Endnote}

1. The failure of the revolution in Animal Farm does not denote any cynicism towards revolution on Orwell's part. As he wrote elsewhere, 'By revolution we become more ourselves, not less' (Orwell, 1994: 188). 